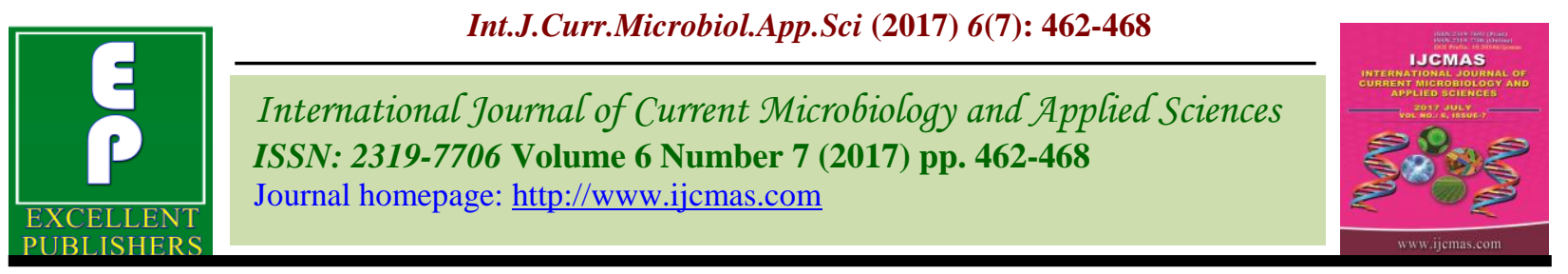

Original Research Article https://doi.org/10.20546/ijcmas.2017.607.055

\title{
Effect of Integrated Nutrient Management in Yield, Growth Attributes and Microbial Population of Sesame (Sesamum indicum)
}

\author{
Gayatri Sahu $^{1 *}$, Nitin Chatterjee ${ }^{1}$ and Goutam Kumar Ghosh ${ }^{2}$ \\ ${ }^{1}$ Department of Agricultural Chemistry and Soil Science, \\ Bidhan Chandra Krishi Viswavidyalaya, Mohanpur, Nadia- 741252, West Bengal, India \\ ${ }^{2}$ Department of Soil Science and Agricultural Chemistry, Visva- Bharati University, \\ Sriniketan - 731 236, West Bengal, India \\ *Corresponding author
}

\begin{tabular}{|c|c|}
\hline & A B S T R A C T \\
\hline $\begin{array}{l}\text { Ke y w o r d s } \\
\text { Sesame, } \\
\text { Macronutrients, } \\
\text { Micronutrients, } \\
\text { Sulphur, FYM, } \\
\text { Azospirillum, } \\
\text { Yield and growth } \\
\text { attributes, } \\
\text { Microbial } \\
\text { population. }\end{array}$ & \multirow{3}{*}{$\begin{array}{l}\text { A field experiment was conducted on sesame during summer season of } 2015 \text { in } \\
\text { red and lateritic soils of West Bengal at the Agricultural Farm of Palli Siksha } \\
\text { Bhavana (Institute of Agriculture), Visva-Bharati, Sriniketan to study the effect of } \\
\text { combined application of macro- and micronutrient fertilizers and biofertilizers on } \\
\text { yield, growth attributes and microbial population of Sesame. The experiment was } \\
\text { laid out in randomized block design. Highest grain yield }\left(7.9 \mathrm{q} \mathrm{ha}^{-1}\right) \text {, stover yield } \\
\left.\left(24.5 \mathrm{q} \text { ha }^{-1}\right) \text {, biological yield ( } 32.4 \mathrm{q} \mathrm{ha}^{-1}\right) \text { and oil yield of sesame was } \\
\text { registered where higher doses of sulphur along with other inorganic fertilizers } \\
\left(\mathrm{N}_{40} \mathrm{P}_{40} \mathrm{~K}_{40} \mathrm{~S}_{5} \mathrm{Zn}_{21} \mathrm{Mo}_{2.0}+\mathrm{FYM}\right) \text { were applied. Plant height }(\mathrm{cm}) \text {, branch no. } \\
\text { per plant, pods per plant is found highest in combined application of inorganic } \\
\text { and organic fertilizers }\left(\mathrm{N}_{40} \mathrm{P}_{40} \mathrm{~K}_{40} \mathrm{Zn}_{10.5} \mathrm{Mo}_{1} \mathrm{~B}_{1.0} \mathrm{~S}_{30}+\text { Azospirillum }+\mathrm{FYM}\right) \text {. } \\
\text { Higher population of Azospirillum was registered in post- harvest soil treated } \\
\text { with Azospirillum along with sulphur, micro and macronutrients treated plots. }\end{array}$} \\
\hline Article Info & \\
\hline $\begin{array}{l}\text { Accepted: } \\
\text { 04 June } 2017 \\
\text { Available Online: } \\
\text { 10 July } 2017\end{array}$ & \\
\hline
\end{tabular}

\section{Introduction}

The demand for vegetable oil in India is increasing steeply owing to increase in population, improvement in standard of living, increasing industrial requirement besides the current global pressure on biofuels. The post green revolution scenario of Indian agriculture encompasses many problems such as stagnation or even decline in production and productivity growth rates of major crops, deterioration of soil fertility, decline in factor productivity, low diversity of production systems and increasing cost of production. These constraints have croppedup partially as a result of continuous cropping without proper nutrient management and indiscriminate use of agrochemicals on soil and crops. Indiscriminate use of high analysis chemical fertilizers resulted in the deficiency of nutrients other than the applied and disturbs the natural equilibrium of nutrient elements in soils (Singh et al., 1995). The problems of micronutrients also generally crops up with the use of high analysis chemical fertilizers having one or two nutrient 
elements (Takkar et al., 1989). The decline in productivity of intensive cropping systems over the years was associated with deficiencies of secondary and micronutrients (Swarup and Ganeshamurthy, 1998). Sustainability of crop production is not a viable proposition either through use of organic manures or chemical fertilizers alone (Singh et al., 2009). Use of chemical fertilizers alone increase the crop yields in the initial year adversely affected the sustainability at later stage. Furthermore, the chemical fertilizers are in short supply, derived from non-renewable sources of energy and are costly. Under these constraints, bioinoculants are the route to alternative strategy and many workers reported the beneficial effects of integrating biofertilizers on crop growth, yield and maintenance of soil fertility (Pattanayak et al., 2001). Azospirillum, an associative diazotroph have been identified as potential microbial inoculants for increasing the productivity of various non-legume crops. Biofertilizer helps in nitrogen fixation, synthesize and secrete many amino acids which influence seed germination, plant growth and yield (Sardana, 1997). FYM is a key fertilizer in organic and sustainable soil management. It contains many of the elements that are needed for plant growth and development. Higher seed yield of sesame can be obtained by integrated use of fertilizer along with FYM and Azospirillum (Purushottam, 2005 and Jaishankar and Wahab, 2005).

Oilseed crops play the second important role in the Indian agricultural economy next to food grains in terms of area and production. The Indian climate is suitable for the cultivation of oilseed crops; therefore, large varieties of oilseeds are cultivated here. Among the oilseed crops, sesame (Sesamum indicum L.) is well known and is one of the oldest crops in the world (Were et al., 2006). It is one of the important oilseed crops in
West Bengal and mainly grown in marginal land with minimum care. The area, production and productivity of sesame are higher in summer season than those of postkharif and kharif seasons (Anonymous, 2006). Lower productivity of sesame is due to use of sub-optimal rate of fertilizer, poor management and cultivation of sesame in marginal and sub-marginal lands where deficiency of macronutrients such as nitrogen, phosphorus, potassium and micronutrient is predominant. Sulphur plays an important role in the primary and secondary plant metabolism as a component of proteins, glucosinolates and other compounds that related to several parameters determining the nutritive quality of crops (Ceccotti, 1996). The response of oilseeds to sulphur is increasing due to increasing of cropping intensity (Chattopaddhyay et al., 2012). It is required for the synthesis of proteins, vitamins and chlorophyll and also $S$ containing amino acids such as cystine, cysteine and methionine which are essential components of proteins (Tisdale et al., 1999). $\mathrm{S}$-application significantly increased the uptake of $\mathrm{N}$ in straw and grain (Badruddin, 1999) thereby increased grain yield.

\section{Materials and Methods}

A field experiment was conducted on sesame during summer season of 2015 in red and lateritic soils of West Bengal at the Agricultural Farm of Palli Siksha Bhavana (Institute of Agriculture), Visva-Bharati, Sriniketan. The experimental farm was situated at $23^{\circ} 39^{\prime} \mathrm{N}$ latitude and $87^{\circ} 42^{\prime} \mathrm{E}$ longitude with an average altitude of $58.9 \mathrm{~m}$ above the mean sea level under sub humid semi-arid region of West Bengal. The soil was acidic ( $\mathrm{pH} 4.35)$, low in organic carbon $(0.32 \%)$, available nitrogen (160 kg ha $\left.{ }^{-1}\right)$, available phosphorus $\left(15.92 \mathrm{~kg} \mathrm{ha}^{-1}\right)$, available potassium $\left(72 \mathrm{~kg} \mathrm{ha}^{-1}\right)$ and available sulphur (11.23 $\left.\mathrm{kg} \mathrm{ha}^{-1}\right)$. The experiment was laid out 
in randomized block design with 15 treatments. As per the treatments specification, fertilizers were applied in the form of urea, Diammonium phosphate (DAP), Murate of potash (MOP) for the source of nitrogen, phosphorus and potassium respectively. Magnesium sulphate $(26.63 \%$ S) was used for the source of sulphur. In the cases of micronutrients Boric acid $(17 \% \mathrm{~B})$, Zinc Sulphate Heptahydrate (21\% Zn), Ammonium molybdate $(54 \% \mathrm{Mo})$ are used for the source of boron, zinc and molybdenum. The sesame seed was inoculated properly with the culture of Azospirillum. All the plots are treated with FYM (5tonnes per ha) except $T_{1}$ whereas $T_{1}$ was treated as control plot where RDF (80: 40: 40kg: $\mathrm{N}: \mathrm{P}_{2} \mathrm{O}_{5}: \mathrm{K}_{2} \mathrm{O}$ ha $^{-1}$ ) was added. Grain yield, stover yield, biological yield, oil yield along with microbial population was calculated. Oil extraction was done by Soxhlet's extraction method. The soil samples were analyzed following standard procedures. The data collected from the experiment at different growth stages was subjected to statistical analysis as described by Gomez and Gomez (1984).

\section{Results and Discussion}

\section{Growth attributes of sesame}

The growth attributes measured in term of plant height, branch no. per plant and pods per plant are presented in table 1 . Combined applications of micro- and macro nutrients along with sulphur and biofertilizers have shown significant improvement in all growth parameters than control in sesame. As regards to plant height, branch number per plant and pods per plant maximum value was obtained in $\begin{array}{llll}\mathrm{T}_{15} & \left(\mathrm{~N}_{40} \mathrm{P}_{40} \mathrm{~K}_{40}\right. & \mathrm{Zn}_{10.5} & \mathrm{Mo}_{1}\end{array}$ $\mathrm{B}_{1.0} \mathrm{~S}_{30}+$ Azospirillum). There is no significant difference between branch numbers per plant between treatments. These treatments recorded a significant higher plant height and pods per plant as compared to control treatment i.e. $\mathrm{T}_{1}$ (RDF) where the plant height was minimum. This might be due to more synthesis of amino acids, increase in chlorophyll content in growing region and improving the photosynthetic activity, ultimately enhancing cell division and thereby increased the crop growth rate. This was evinced through the studies of Dubey and Khan (1993). The results clearly indicate that integrated use of chemical fertilizer, organic manure and biofertilizer was better than application of chemical and organic or biofertilizer or chemical sources of nutrient alone. This may be due to supply of nutrients from diversified sources and prolonged availability of nutrients to the growing plants. The beneficial role of free living nitrogen fixing microorganisms for enhancing plant growth through their ability in nitrogen fixation as well as the effect of their metabolites secretion on the crop may also be attributed for the same. Using organic manure to supplement chemical fertilizer with respect to $\mathrm{N}$ might have resulted in good supply of potassium also. These results are in agreement with Jaishankar and Wahab (2005), Imayavaramban et al., (2002) and Verma et al., (2012).

\section{Yield components of sesame}

Sesame seed yield was affected significantly by integrated application of fertilizer in different treatments over control (Table 2). Combined application of inorganic nutrients along with micronutrients and sulphur has a great role to increase the seed yield of sesame as compared to only inorganically treated nutrients. The seed yield varied between 4.85 to $7.92 \mathrm{q} \mathrm{ha}{ }^{-1}$. The highest grain yield $(7.92 \mathrm{q}$ $\mathrm{ha}^{-1}$ ) was observed in $\mathrm{T}_{13}$ $\left(\mathrm{N}_{40} \mathrm{P}_{40} \mathrm{~K}_{40} \mathrm{~S}_{45} \mathrm{Zn}_{21} \mathrm{Mo}_{2.0}\right)$ followed by $\mathrm{T}_{15}$ which were treated by both micronutrients ( $\mathrm{Zn}, \mathrm{B}$ and $\mathrm{Mo}$ ) and sulphur along with macronutrients (NPK) and lowest seed yield $\left(4.85 \mathrm{q} \mathrm{ha}^{-1}\right)$ was recorded in control. It is interesting to note that Azospirillum treated 
plots recorded higher yield than only NPK and NPK with micronutrients. Integrated nutrient management is reported to be the best option to increase the yield of the crops and maintaining soil health. The results clearly indicate that integrated use of organic and inorganic fertilizers in various combinations or alone performed better with regards to seed yield, stover yield, and biological yield of sesame. It is interesting to note that application of either B, or Mo or $\mathrm{Zn}$ along with NPK boosted the yield of sesame significantly.

Like seed yield, stover yield was significantly increased by different treatments under study. In case of stover yield the ranges varied between 15.93 to $24.50 \mathrm{q} \mathrm{ha}^{-1}$. Like grain yield the highest yield was also found in $\mathrm{T}_{13}$ i.e. $24.50 \mathrm{qha}^{-1}$ followed by $\mathrm{T}_{15}$ i.e. $23.27 \mathrm{q} \mathrm{ha}^{-1}$. Lowest stover yield was found in control i.e. $15.93 \mathrm{q} \mathrm{ha}^{-1}$. It was also found that Azospirillum and FYM treated plots recorded higher yield than only NPK and NPK with micronutrients treated plots. Here also combined application of macro and micronutrients along with sulphur has a great role to increase the stover yield of sesame.

Depending upon stover yield and seed yield the biological yield was summed up. The biological yield was found highest in $\mathrm{T}_{13}$ i.e. $32.42 \mathrm{q} \mathrm{ha}^{-1}$ followed by $\mathrm{T}_{15}$ i.e. $31.05 \mathrm{q} \mathrm{ha}^{-1}$ and lowest value was observed in control i.e. $20.79 \mathrm{q} \mathrm{ha}{ }^{-1}$. Harvest index was also calculated depending upon the seed yield and biological yield. The ranges of harvest index were observed in case of sesame from 23.34$28.82 \%$. The highest harvest index was found in $\mathrm{T}_{13}$ and lowest value was observed in $\mathrm{T}_{3}$. Improvement of yield is due to combined application of macro and micronutrients along with sulphur. In case of $T_{13}$ integrated use of fertilizer was done by combined application of macro and micronutrients along with higher doses of sulphur helps to get higher yield in sesame.

Table.1 Effect of INM in growth attributes of sesame

\begin{tabular}{|c|c|c|c|}
\hline Treatment Details & $\begin{array}{l}\text { Plant ht } \\
(\mathrm{cm})\end{array}$ & $\begin{array}{c}\text { Branch } \\
\text { no.per plant }\end{array}$ & $\begin{array}{c}\text { Pods per } \\
\text { Plant }\end{array}$ \\
\hline $\mathrm{T}_{1-}$ Control(RDF) & 82.33 & 4.33 & 44.33 \\
\hline $\mathrm{T}_{2}-\mathrm{N}_{40} \mathrm{P}_{40} \mathrm{~K}_{40}+\mathrm{FYM}$ & 88.33 & 5.00 & 52.00 \\
\hline $\mathrm{T}_{3}-\mathrm{N}_{40} \mathrm{P}_{40} \mathrm{~K}_{60}+\mathrm{FYM}$ & 84.67 & 4.67 & 55.33 \\
\hline $\mathrm{T}_{4}-\mathrm{N}_{40} \mathrm{P}_{40} \mathrm{~K}_{80}+\mathrm{FYM}$ & 91.67 & 5.00 & 59.00 \\
\hline $\mathrm{T}_{5}-\mathrm{N}_{40} \mathrm{P}_{40} \mathrm{~K}_{40} \mathrm{Mo}_{1 \mathrm{~kg}}+\mathrm{FYM}$ & 92.67 & 6.00 & 59.33 \\
\hline $\mathrm{T}_{6}-\mathrm{N}_{40} \mathrm{P}_{40} \mathrm{~K}_{40} \mathrm{Bo}_{0.5}+\mathrm{FYM}$ & 97.33 & 5.67 & 58.67 \\
\hline $\mathrm{T}_{7}-\mathrm{N}_{40} \mathrm{P}_{40} \mathrm{~K}_{40} \mathrm{Zn}_{5}+\mathrm{FYM}$ & 100.67 & 5.00 & 60.67 \\
\hline $\mathrm{T}_{8}-\mathrm{N}_{40} \mathrm{P}_{40} \mathrm{~K}_{40} \mathrm{Zn}_{10.5}+\mathrm{FYM}$ & 111.00 & 6.00 & 61.33 \\
\hline $\mathrm{T}_{9}-\mathrm{N}_{40} \mathrm{P}_{40} \mathrm{~K}_{40} \mathrm{Zn}_{21}+\mathrm{FYM}$ & 114.00 & 6.00 & 64.33 \\
\hline $\mathrm{T}_{10}-\mathrm{N}_{40} \mathrm{P}_{40} \mathrm{~K}_{40}+$ Azospirillum+ FYM & 122.33 & 6.33 & 66.33 \\
\hline $\mathrm{T}_{11}-\mathrm{N}_{40} \mathrm{P}_{40} \mathrm{~K}_{40} \mathrm{~S}_{15}+\mathrm{FYM}$ & 126.67 & 6.45 & 66.67 \\
\hline $\mathrm{T}_{12}-\mathrm{N}_{40} \mathrm{P}_{40} \mathrm{~K}_{40} \mathrm{~S}_{30} \mathrm{Zn}_{10.5} \mathrm{Mo}_{1.0}+\mathrm{FYM}$ & 128.00 & 6.47 & 69.67 \\
\hline $\mathrm{T}_{13}-\mathrm{N}_{40} \mathrm{P}_{40} \mathrm{~K}_{40} \mathrm{~S}_{45} \mathrm{Zn}_{21} \mathrm{Mo}_{2.0}+\mathrm{FYM}$ & 129.67 & 6.49 & 76.67 \\
\hline $\mathrm{T}_{14}-\mathrm{N}_{40} \mathrm{P}_{40} \mathrm{~K}_{40} \mathrm{Zn}_{10.5} \mathrm{Mo}_{1} \mathrm{~B}_{0.5} \mathrm{~S}_{30}+\mathrm{FYM}$ & 138.33 & 6.52 & 77.67 \\
\hline $\mathrm{T}_{15}-\mathrm{N}_{40} \mathrm{P}_{40} \mathrm{~K}_{40} \mathrm{Zn}_{10.5} \mathrm{Mo}_{1} \mathrm{~B}_{1.0} \mathrm{~S}_{30}+$ Azospirillum $+\mathrm{FYM}$ & 143.67 & 6.97 & 80.00 \\
\hline $\operatorname{SEm}( \pm)$ & 3.40 & 0.46 & 2.22 \\
\hline $\mathrm{CD}(\mathrm{P}=0.05)$ & 10.49 & 1.43 & 6.86 \\
\hline
\end{tabular}


Table.2 Effect of INM on yield components of sesame

\begin{tabular}{|c|c|c|c|c|}
\hline Treatment Details & Seed Yield & $\begin{array}{c}\text { Stover } \\
\text { Yield }\end{array}$ & $\begin{array}{l}\text { Biological } \\
\text { Yield }\end{array}$ & \multirow[t]{2}{*}{$\begin{array}{l}\text { Oil Yield } \\
\left(\mathrm{kgha}^{-1}\right)\end{array}$} \\
\hline & \multicolumn{3}{|c|}{$\left(\mathrm{Qha}^{-1}\right)$} & \\
\hline $\mathrm{T}_{1}-$ Control(RDF) & 4.85 & 15.93 & 20.79 & 2.0 \\
\hline $\mathrm{T}_{2}-\mathrm{N}_{40} \mathrm{P}_{40} \mathrm{~K}_{40}+\mathrm{FYM}$ & 5.26 & 16.60 & 21.86 & 2.5 \\
\hline $\mathrm{T}_{3}-\mathrm{N}_{40} \mathrm{P}_{40} \mathrm{~K}_{60}+\mathrm{FYM}$ & 5.24 & 17.23 & 22.47 & 2.5 \\
\hline $\mathrm{T}_{4}-\mathrm{N}_{40} \mathrm{P}_{40} \mathrm{~K}_{80}+\mathrm{FYM}$ & 5.86 & 17.10 & 22.96 & 2.8 \\
\hline $\mathrm{T}_{5}-\mathrm{N}_{40} \mathrm{P}_{40} \mathrm{~K}_{40} \mathrm{Mo}_{1 \mathrm{~kg}}+\mathrm{FYM}$ & 5.97 & 17.20 & 23.17 & 2.9 \\
\hline $\mathrm{T}_{6}-\mathrm{N}_{40} \mathrm{P}_{40} \mathrm{~K}_{40} \mathrm{Bo}_{0.5}+\mathrm{FYM}$ & 6.25 & 17.47 & 23.72 & 3.2 \\
\hline $\mathrm{T}_{7}-\mathrm{N}_{40} \mathrm{P}_{40} \mathrm{~K}_{40} \mathrm{Zn}_{5}+\mathrm{FYM}$ & 6.34 & 18.00 & 24.34 & 3.4 \\
\hline $\mathrm{T}_{8}-\mathrm{N}_{40} \mathrm{P}_{40} \mathrm{~K}_{40} \mathrm{Zn}_{10.5}+\mathrm{FYM}$ & 6.37 & 18.80 & 25.17 & 3.3 \\
\hline $\mathrm{T}_{9}-\mathrm{N}_{40} \mathrm{P}_{40} \mathrm{~K}_{40} \mathrm{Zn}_{21}+\mathrm{FYM}$ & 6.53 & 19.50 & 26.03 & 3.5 \\
\hline $\mathrm{T}_{10}-\mathrm{N}_{40} \mathrm{P}_{40} \mathrm{~K}_{40}+$ Azospirillum+ FYM & 6.84 & 21.57 & 28.40 & 3.7 \\
\hline $\mathrm{T}_{11}-\mathrm{N}_{40} \mathrm{P}_{40} \mathrm{~K}_{40} \mathrm{~S}_{15}+\mathrm{FYM}$ & 6.93 & 22.37 & 29.30 & 3.8 \\
\hline $\mathrm{T}_{12}-\mathrm{N}_{40} \mathrm{P}_{40} \mathrm{~K}_{40} \mathrm{~S}_{30} \mathrm{Zn}_{10.5} \mathrm{Mo}_{1.0}+\mathrm{FYM}$ & 7.17 & 22.83 & 30.01 & 4.0 \\
\hline $\mathrm{T}_{13}-\mathrm{N}_{40} \mathrm{P}_{40} \mathrm{~K}_{40} \mathrm{~S}_{45} \mathrm{Zn}_{21} \mathrm{Mo}_{2.0}+\mathrm{FYM}$ & 7.92 & 24.50 & 32.42 & 4.5 \\
\hline $\mathrm{T}_{14}-\mathrm{N}_{40} \mathrm{P}_{40} \mathrm{~K}_{40} \mathrm{Zn}_{10.5} \mathrm{Mo}_{1} \mathrm{~B}_{0.5} \mathrm{~S}_{30}+\mathrm{FYM}$ & 7.55 & 23.07 & 30.61 & 4.2 \\
\hline $\begin{array}{l}\mathrm{T}_{15}-\mathrm{N}_{40} \mathrm{P}_{40} \mathrm{~K}_{40} \mathrm{Zn}_{10.5} \mathrm{Mo}_{1} \mathrm{~B}_{1.0} \mathrm{~S}_{30}+ \\
\text { Azospirillum+ FYM }\end{array}$ & 7.77 & 23.27 & 31.05 & 4.4 \\
\hline $\operatorname{SEm}( \pm)$ & 0.064 & 0.227 & 0.243 & 0.081 \\
\hline $\mathrm{CD}(\mathrm{P}=0.05)$ & 0.199 & 0.702 & 0.749 & 0.251 \\
\hline
\end{tabular}

Table.3 Effect of INM on microbial population

\begin{tabular}{|c|c|}
\hline Treatment Details & $\begin{array}{c}\text { Azospirillum } \\
\left(\text { No. } \times 10^{6} \mathrm{cfu} \mathrm{g}^{-1}\right)\end{array}$ \\
\hline $\mathrm{T}_{1}-$ Control(RDF) & 2.44 \\
\hline $\mathrm{T}_{2}-\mathrm{N}_{40} \mathrm{P}_{40} \mathrm{~K}_{40}+\mathrm{FYM}$ & 2.85 \\
\hline $\mathrm{T}_{3}-\mathrm{N}_{40} \mathrm{P}_{40} \mathrm{~K}_{60}+\mathrm{FYM}$ & 2.84 \\
\hline $\mathrm{T}_{4}-\mathrm{N}_{40} \mathrm{P}_{40} \mathrm{~K}_{80}+\mathrm{FYM}$ & 2.94 \\
\hline $\mathrm{T}_{5}-\mathrm{N}_{40} \mathrm{P}_{40} \mathrm{~K}_{40} \mathrm{Mo}_{1 \mathrm{~kg}}+\mathrm{FYM}$ & 3.01 \\
\hline $\mathrm{T}_{6}-\mathrm{N}_{40} \mathrm{P}_{40} \mathrm{~K}_{40} \mathrm{Bo}_{0.5}+\mathrm{FYM}$ & 3.01 \\
\hline $\mathrm{T}_{7}-\mathrm{N}_{40} \mathrm{P}_{40} \mathrm{~K}_{40} \mathrm{Zn}_{5}+\mathrm{FYM}$ & 2.85 \\
\hline $\mathrm{T}_{8}-\mathrm{N}_{40} \mathrm{P}_{40} \mathrm{~K}_{40} \mathrm{Zn}_{10.5}+\mathrm{FYM}$ & 3.36 \\
\hline $\mathrm{T}_{9}-\mathrm{N}_{40} \mathrm{P}_{40} \mathrm{~K}_{40} \mathrm{Zn}_{21}+\mathrm{FYM}$ & 3.22 \\
\hline $\mathrm{T}_{10}-\mathrm{N}_{40} \mathrm{P}_{40} \mathrm{~K}_{40}+$ Azospirillum+ FYM & 7.48 \\
\hline $\mathrm{T}_{11}-\mathrm{N}_{40} \mathrm{P}_{40} \mathrm{~K}_{40} \mathrm{~S}_{15}+\mathrm{FYM}$ & 3.25 \\
\hline $\mathrm{T}_{12}-\mathrm{N}_{40} \mathrm{P}_{40} \mathrm{~K}_{40} \mathrm{~S}_{30} \mathrm{Zn}_{10.5} \mathrm{Mo}_{1.0}+\mathrm{FYM}$ & 3.77 \\
\hline $\mathrm{T}_{13}-\mathrm{N}_{40} \mathrm{P}_{40} \mathrm{~K}_{40} \mathrm{~S}_{45} \mathrm{Zn}_{21} \mathrm{Mo}_{2.0}+\mathrm{FYM}$ & 2.93 \\
\hline $\mathrm{T}_{14}-\mathrm{N}_{40} \mathrm{P}_{40} \mathrm{~K}_{40} \mathrm{Zn}_{10.5} \mathrm{Mo}_{1} \mathrm{~B}_{0.5} \mathrm{~S}_{30}+\mathrm{FYM}$ & 3.00 \\
\hline $\mathrm{T}_{15}-\mathrm{N}_{40} \mathrm{P}_{40} \mathrm{~K}_{40} \mathrm{Zn}_{10.5} \mathrm{Mo}_{1} \mathrm{~B}_{1.0} \mathrm{~S}_{30}+$ Azospirillum $+\mathrm{FYM}$ & 9.36 \\
\hline $\operatorname{SEm}( \pm)$ & 0.221 \\
\hline $\mathrm{CD}(\mathrm{P}=0.05)$ & 0.681 \\
\hline
\end{tabular}


The value oil yield varied from $2.0 \mathrm{q} \mathrm{ha}^{-1}$ to $4.5 \mathrm{q} \mathrm{ha}{ }^{-1}$. The minimum value was recorded in control plot. The highest oil yield was observed in T13 i.e. $4.5 \mathrm{q} \mathrm{ha}^{-1}$ followed by $\mathrm{T} 15$ i.e. $4.4 \mathrm{q} \mathrm{ha}^{-1}$. The highest value was observed due to application of high doses of sulphur i.e. @ 45 $\mathrm{kg} \mathrm{ha}^{-1}$. Increased oil content and oil yield due to application of nitrogen and sulphur was also reported by Das and Das (1996). The acetic thiolinase, a sulphur based enzyme in the presence of $\mathrm{S}$ convert acetyl Co-A to melonyl Co-A, rapidly resulting in higher oil content in seed crops (Krishnamurthy and Mathan, 1996).

\section{Microbial population}

Analysis of the data of microbial population in soil after harvesting of sesame is presented in table 3 . The microbial population mainly includes the Azospirillum population. The effect of INM treatments on population of Azospirillum in soil after harvest of sesame is presented in table 3 .

Application of Azospirillum along with NPK did not show any significant difference in case of growth and yield attributes in sesame but application of Azospirillum along with FYM, sulphur, micro and macronutrients i.e. $\mathrm{T}_{15}$ recorded significant difference in case of growth parameters, yield attributes and uptake of nutrients.

In case of seed, stover, biological yield and oil yield $\mathrm{T}_{15}$ gave comparatively higher yield than all other treatments except $\mathrm{T}_{13}$ which was treated by high dose of sulphur i.e. @ $45 \mathrm{kgha}^{-1}$. In case of oil content $\mathrm{T}_{15}$ gave the highest yield. The highest population of Azospirillum was observed in $\mathrm{T}_{15}$ followed by $\mathrm{T}_{10}$ and lowest population was observed in control.

In conclusion, Integrated Nutrient Management is one of the important issues for sustainable crop production. The result of the study revealed that integrated application of NPK with sulphur, boron, molybdenum, zinc along with biofertilizer recorded higher growth attributes, grain yield, total biological yield, oil yield and microbial population. Combined application of sulphur, boron, molybdenum, zinc increase the use efficiency of nitrogen, phosphorus and potassium.

Integrated nutrient applications are more beneficial when the rate of the nutrient application is below the normal rate. It also improved the crop yields, quality of the produce as well as improves the soil fertility, thus the overall profit of the farmers. Thus, it may be recommended for the farmers of red and lateritic belt of West Bengal.

\section{References}

Anonymous. 2006. Package of Organic Practices for Brinjal, Rice, Sesame and Taro. Development Research Communication and Services Centre. Available from http://www.drcsc.org.

Badruddin, M. 1999. The effect of sulphur deficiency onion accumulation with special reference to $15 \mathrm{~N}$ and $35 \mathrm{~S}$ transport and metabolism in chickpea. Ph.D Thesis, University of Dhaka, Bangladesh.

Ceccotti, S.P. 1996. Plant nutrition sulphur-A review of nutrient balance, environment impact and fertilizers. Fertilizer research: an international journal on fertilizer use; 43: 117-125.

Chattopaddhyay, S., and Ghosh, G.K. 2012. Response of Rapeseed (Brassica juncea L.) to various Sources and Levels of Sulphur in Red and Lateritic Soils of West Bengal, India. International Journal of Plant, Animal and Environmental Sciences 2(4): $50-59$.

Das, K.N. and Das, K. 1995. Effect of sulphur and nitrogen fertilizer on growth and yield of toria (Brassica campestris sub sp. oleifera var. toria). Indian Journal of Agronomy. 40: 329-331

Dubey, O.P., and Khan, R.A. 1993. Effect of nitrogen and sulphur content in Indian 
mustard and their residual balance in soil. Indian Journal of Agronomy 38: 582-587.

Gomez, K.A., and Gomez, A.A. 1984. Statistical Procedures for Agricultural Research. A Wiley- Interscience Publication, New York, pp. 130-139.

Imayavaramban, V., Thanunathan, K., Singaravel, R., and Manickam, G., 2002. Studies on the influence of integrated nutrient management on growth, yield parameters and seed yield of sesame (Sesamum indicum L.). Crop Research 24(2), 309-313.

Jaishankar, S., and Wahab, K. 2005. Effect of integrated nutrient management on the growth, yield components and yield of sesame. Sesame and Safflower Newsletter 20,732 .

Krishnamurthy, V.V., and Mathan, K.K. 1996. Effect of sulphur on yield of groundnut. Madras. Agric. J. 83: 640-642.

Pattanayak, S.K., Mohanty, R.K., and Sethy, A.K. 2001. Response of okra to Azotobactor, Azospirillum and FYM. Second North Eastern Regional Conference on Biofertilizers, Assam Agricultural University, Jorhat, Assam.

Purushottam, G. 2005. Integrated nutrient management in sesame (Sesamum indicum L.) and its residual effect on succeeding chickpea (Cicer arietinum L.). M.Sc. (Ag.) in Agronomy Thesis submitted to the University of Agricultural Sciences, Dharwad, Karnataka.

Sardana, V. 1997. Agronomic Evaluation of Bioinoculants to supplement inorganic fertilizers for sustained crop production- A critical review. Agricultural Research. 18, 69-95
Singh, B., Singh, Y., and Sekhon, G.S. 1995. Fertilizer $\mathrm{N}$ uses efficiency and nitrate pollution of groundwater in developing countries. Journal of Contaminant Hydrology. 20: 167-184.

Singh, S.P., Dhayani, B.P., Shahi, U.P., Kumar, A., Singh, R.R., Kumar, Y., Kumar, S., and Baliyan, V. 2009. Impact of Integrated Nutrient Management on yield and nutrient uptake in rice (Oryza sativa) Wheat (Triticum aestivum) under ricewheat cropping system in sandy loam soil. Indian Journal of Agril. Sc. 79: 65-69

Swarup, A., and Ganeshamurthy, A.N. 1998. Emerging nutrient deficiencies under intensive cropping systems and remedial measures for sustainable high productivity. Fertilizer News; 43(7), 37-40 and 43-50

Takkar, P.N., Chhibba, I.M., and Mehta, S.K. 1989. Twenty years of coordinated research on Micronutrients in Soil and Plants, 196787, Bulletin 1, Indian Institute of Soil Science, Bhopal.

Tisdale, P.P., Poongothai, S., Savithri, R.K., and Bijujoseph, O.P. 1999. Influence of gypsum and green leaf manure application on rice. Journal of the Indian Society of Soil Science; 47(1), 96-99.

Verma, S., Saxena, R., and Singh, H.V., 2012. Integrated nutrient management in sesame (Sesamum indicum L.). Bioinfolet 9(4), 576-579.

Were, B.A., Onkware, A.O., Gudu, S., Welander, M., and Carlsson, A.S. 2006. Seed oil content and fatty acid composition in east African sesame (Sesamum indicum L.) accessions evaluated over 3 years. Field Crop Res. 97:254-260.

\section{How to cite this article:}

Gayatri Sahu, Nitin Chatterjee and Goutam Kumar Ghosh. 2017. Effect of Integrated Nutrient Management in Yield, Growth Attributes and Microbial Population of Sesame (Sesamum indicum). Int.J.Curr.Microbiol.App.Sci. 6(7): 462-468. doi: https://doi.org/10.20546/ijcmas.2017.607.055 